Año XLIX. urtea

$123-2017$

Urtarrila - ekaina

Enero - junio

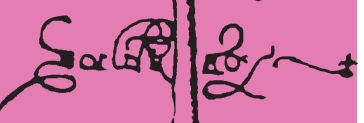

ters

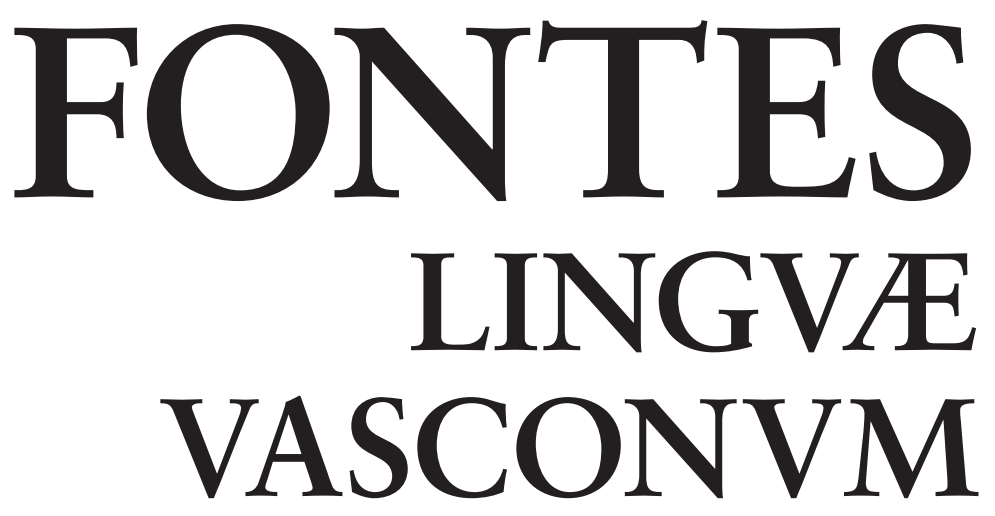

STVDIA ET DOCVMENTA

SEPARATA

Zatoz! Agindua da!

Euskal aginteraren

azterketa formal baterako

lehen urratsak

Itziar ORBEGOZO

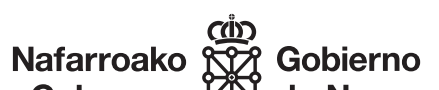

Gobernua LSO de Navarra

0000 


\title{
Zatoz! Agindua da! Euskal aginteraren azterketa formal baterako lehen urratsak
}

¡Ven! ¡Es una orden!

Primeros pasos hacia un análisis formal de las oraciones imperativas del euskera

Come here! It is an order!

First steps towards a formal approach of Basque imperative clauses

\section{Itziar ORBEGOZO}

Universidad del País Vasco/Euskal Herriko Unibertsitatea (UPV/EHU)

itziar.orbegozo@ehu.eus

\begin{abstract}
Eskerrak eman nahi dizkiet, hasteko, $F L V$ aldizkariko bi ebaluatzaile izengabeei, egindako zuzenketa, iruzkin eta iradokizun guztiengatik. Bestetik, eskerrik beroenak eman nahi dizkiot Beatriz Fernándezi, lan honek oinarri duen Gradu Amaierako Lanean zuzendari izan nuenari eta master tesiko zuzendari ere badudanari. Halaber, bihoakie nire esker ona epaimahaian izan nituen Pablo Albizu, Xabier Artiagoitia eta Maia Duguineri euren iruzkin eta iradokizunengatik. Lan honek, Espainiako Ekonomia eta Lehiakortasun Ministerioaren diru laguntza eta babesa jaso du «FFI2014-51878-P» ikerketa proiektuaren barruko «PIC 168/16» ikertzaile kontratuaren bidez.
\end{abstract}




\section{LABURPENA}

Lan honen helburua euskal aginte perpausen azterketa formalerako lehen urratsak ematea da. Aginte perpausen berezitasunek, besteak beste, subjektuarekin dute zerikusia: batetik, isileko subjektua 2. pertsona gisa interpretatzen da beti, baita pertsona komunztadurarik ez dagoenean ere, eta bestetik, subjektua isil daiteke subjektu isiltzerik gabeko hizkuntzetan. Lan honetan erakutsiko denez, ezaugarri hauek azal daitezke aginte perpausetan 2. pertsonako ezaugarriak dituen islapen funtzional bat dagoela proposatuz (Zanuttini, 2008). Orobat, proposamena euskarara ekarrita ikusiko denez, 2. pertsonakoak ez diren subjektuak dituzten aginte perpausak ere azal daitezke ildo beretik. Azkenik, agintera eta ezeztapena aldi berean gertatzen direnean sortzen diren zenbait gertakari azalduko ditut.

Gako hitzak: agintera; subjektua; mintzakidea; sintagma jusiboa; hizkuntza aldakortasuna.

\section{RESUMEN}

El objetivo de este trabajo es dar los primeros pasos hacia un análisis formal de las oraciones imperativas del euskera. Una de las características distintivas de estas oraciones tiene que ver con el sujeto: por un lado, el sujeto elidido siempre se interpreta como sujeto de 2. ${ }^{a}$ persona, y por otro, el sujeto se puede silenciar incluso en lenguas sin elisión de sujeto. Estas propiedades pueden explicarse mediante la presencia de una proyección funcional con rasgos de $2 .^{a}$ persona (Zanuttini, 2008). Asimismo, este análisis permite explicar las oraciones imperativas con sujetos diferentes al de $2 .^{a}$ persona, tal y como mostraré extendiendo la propuesta de Zanuttini al euskera. Por último, analizaré algunos de los fenómenos que emergen de las oraciones imperativas negativas.

Palabras clave: imperativos; sujeto; destinatario; sintagma yusivo; variación lingüística.

\section{ABSTRACT}

The main objective of this article is to take the first steps towards a formal approach of Basque imperative clauses. One of the most distinctive characteristics of these clauses has to do with the subject: firstly, the null subject of imperatives is always interpreted as the addressee, even when there is not any person mark in the verb, and secondly, languages that do not allow declarative or interrogative null subjects allow null imperative subjects. These properties can be explained proposing a functional projection with $2^{\text {nd }}$ person features as in Zanuttini (2008). This proposal can also explain imperatives with other kind of subjects, as I will show in exploring Basque imperatives. Last but not least, some phenomena emerging from negative imperatives will be also explored.

Keywords: Imperatives; subject; addressee; jusive phrase; language variation. 
1. Atarikoak. 2. Aginte Perpausa. 3. Euskal aginteraren eZaugarriak. 4. AginTERAKO SUBJEKTUA. HizKUNTZA ALDAKORTASUNA. 4.1. Aginterako azaleko subjektua mintzakidea denean. 4.2. Aginterako sakoneko subjektua mintzakidea edo hiztuna izan daitekeenean. 4.3. Aginterako subjektua mintzakidea edo hiztuna ez den beste bat izan daitekeenean. 4.4. Tarteko ondorioak. 5. EUSKAL AGINTERAREN SINTAXIA INGELESAREN ANALISI SINTAKTIKOAREN ARGITAN. 6. AGINTERAKO EZEZTAPENEAN SAKONDUZ. 7. ONDORIOAK. 8. ERREFERENTZIAK.

\section{ATARIKOAK}

Euskarazko aginte perpausen inguruko azterketen gabezia ikusita, lan honen xedea aginteraren azterketa formal baterako lehen urratsak ematea da. Horretarako, batez ere Zanuttini-k (2008) eta Alcázar eta Saltarelli-k (2014) ingelesezko eta beste zenbait hizkuntzatako aginte perpausez esan dutena euskarara ekar daitekeen aztertuko dut.

Aginte perpausen ezaugarri garrantzitsuenetako bat subjektuaren eta diskurtsoko partaideen arteko lotura estua da. Lotura hau azaltzeko, Zanuttini-k (2008) aginte perpausetan subjektua baino goragoko islapen bat dagoela proposatzen du, Sintagma Jusibo deritzona. Lan honetan, islapen hau euskarazko aginte perpausetan ere badagoela proposatuko dut eta bere ondorioak zeintzuk diren erakutsiko. Horrez gain, euskal aginteraren beste zenbait ezaugarri ere azalduko ditut.

Helburu hori betetzeko, lehenik eta behin, 2. atalean, aginteraren ezaugarri orokorrak aztertuko ditut munduko beste hizkuntza batzuetan (batez ere indoeuroparretan) oinarrituta egin diren zenbait lan kontuan hartuz. Ondoren, 3. atalean, euskal aginteraren ezaugarri batzuen berri emango dut. 4. atalean, aginterako subjektuak hizkuntzen artean erakusten dituen desberdintasunak zertan diren azalduko dut, eta desberdintasun horien azterketatik ondorio batzuk aterako ditut. Jarraian, beste hizkuntza batzuk oinarri hartuz egin diren ikerketetako orokorpenak euskarara ekartzerik dagoen aztertuko dut, subjektuaren aldetik, 5. atalean, eta aginte perpausetako ezeztapenaren aldetik, 6. atalean. Bukatzeko, 7. atalean, lanaren ondorioei egingo diet tartea. 


\section{AGINTE PERPAUSA}

Ingelesez imperative eta imperative clause izenez ezagunak diren perpausak (Hualde \& Ortiz de Urbina, 2003) agintera eta aginte perpaus izenekin azaltzen dira euskal gramatiketan (Euskaltzaindia, 1987; Sareko Euskal Gramatika). Beraz, berariazko aditz modu bati deitzen zaio agintera eta aditz modu berezi hau barnean duen perpausari, aginte perpausa.

Aginteraren ezaugarri nagusiekin hasiz, sintaxiari dagokionez, aginterako subjektuak adierazpen eta galde perpausetako subjektuak ez bezalakoak dira, izan ere, isileko subjektu interpretagarria dute, baita subjektu isiltzerik gabeko ingelesa bezalako hizkuntzetan ere (ikus Duguine, 2010 eta bertako aipamenak):

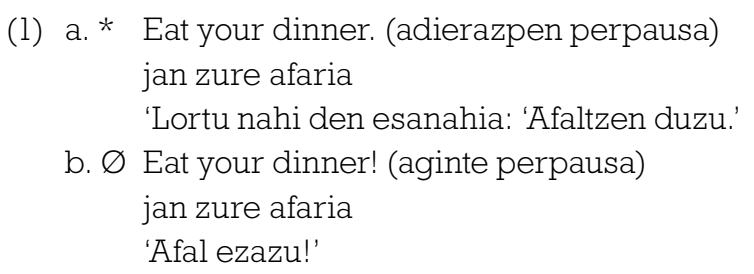

Euskaraz, komunztadurarik gabeko aginte perpausetan ere interpretagarria da subjektua:

(2) Afaldu!

Denbora markapenari dagokionez, irrealisen interpretazioa dute, eta semantikari bagagozkio, berriz, aginte perpausek betebehar bat ezartzen dute. Portner-ek (2005) aginte perpausen semantikari buruz esaten du ezaugarriak adierazten dituztela eta aginteraren indarra, eskakizuna ${ }^{1}$ deitzen duena, perpausak adierazitako ezaugarria mintzakidearen eginbeharren zerrendari gehitzean datzala.

Bestalde, aginterak hautatzen duen predikatu motari dagokionez, badirudi ezin direla edozein predikaturekin batera azaldu: kontrola daitezkeen ekintzak adierazten dituzten aditzekin erabiltzen da agintera (Birjulin \& Xrakovskij, 2001 apud Alcázar \& Saltarelli, 2014, 19).

1 Itzulpen hauek erabiliko dira lan honetan: aginte perpaus kanoniko edo benetakoa = core imperative, canonical imperative; aginte perpaus ez-kanoniko = Set B imperative, non-canonical imperative; agintera arazle = causative imperative; bigarren eskuko agintera = proxy or secondhand imperative; bokatibo = vocative; egile $=$ agent, agentive, performer; eginbeharren zerrenda $=$ To-Do List; eskakizuna = requiring; hiztuna = speaker; hortatibo = hortative; indar direkzionala = directive force; mintzakidea = addressee; Sintagma Jusibo = jussive phrase. 


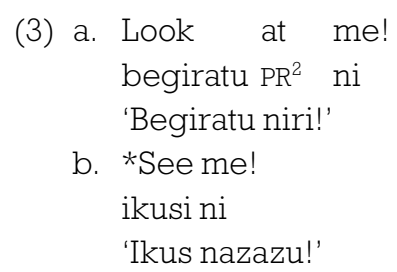

Perpaus horien euskal itzulpenetan ikus daitekeenez, (4a) eta (4b)-n, biak dira onargarriak. Ikus aditzak, beraz, ez du ingelesezko see aditzak bezala jokatzen, aginte perpausetan behintzat, kontrola daitekeen ekintza bat adierazten baitu.

(4) a. Begira iezadazu!

b. Ikus nazazu!

Esan beharra dago autoreen artean aldea dagoela aginteraren barruan sartzen dituzten perpaus moten eta zenbait ezaugarriren aldetik, baina, badirudi denak bat datozela ohiko edo benetako aginte perpaus gisa 2. pertsonako subjektua duten perpausak hartzearekin.

Alabaina, 2. pertsonakoak bezala, 1. pertsonakoak ere aginte perpaus gisa ulertzeko arrazoiak badaude, hainbat ezaugarri partekatzen dituzte-eta. Biak diskurtsoko pertsonei lotuta daude: 2 . pertsona azaltzen den perpausetan aginterak adierazitako betekizuna diskurtsoko mintzakidearengan ezartzen da; aldiz, 1. pertsona azaltzen den kasuetan, betekizuna hiztunarengan (singularra bada) eta hiztun nahiz mintzakidearengan (plurala bada) ezartzen da (Portner, 2005). Azpimarratzekoa da, azkeneko kasuan, agintera adierazpen eta galde perpausetatik bereizten dela, izan ere, aginte perpausetan pluralak adierazten dituen pertsonak beti diskurtsoko mintzakidea eta hiztuna dira. Hori dela eta, (6b)-ko adierazpen perpausa gramatikala da 1. pertsona pluralak 3. pertsona barnebiltzen badu ere, eta, $(5 \mathrm{~b})$-ko aginte perpausa, berriz, ezgramatikala.

(5) a. Goazen etxera! (Zu eta ni)

b. ${ }^{*}$ Goazen etxera! (Hura eta ni)

(6) a. Etxera goaz. (Zu eta ni)

b. Etxera goaz. (Hura eta ni)

3. pertsonako subjektua duten perpausei dagokienez, aginteratik kanpo ulertu izan badira ere, Alcázar eta Saltarelliren $(2014,6)$ arabera, ezaugarri garrantzitsu batzuetan

2 Lan honetan zehar laburdura hauek azalduko dira: $\mathrm{ABS}=$ absolutiboa; $\mathrm{AGN}=$ agintera; $\mathrm{ART}=$ artikulua; $\mathrm{AUX}=$ aditz laguntzailea, $\mathrm{DAT}=$ datiboa; $\mathrm{ERG}=$ ergatiboa; $\mathrm{EZ}=$ ezeztapen partikula; $\mathrm{F}$ = femeninoa; $\mathrm{INF}=$ infinitiboa; KONP = konplementatzailea; KONPS = konplemetatzaile sintagma; $\mathrm{LAG}=$ aditz laguntzailea; $\mathrm{M}$ = maskulinoa; $\mathrm{NOM}=$ nominatiboa; $\mathrm{PL}=$ plurala POS = posesiboa; $\mathrm{PR}=$ preposizioa; $\mathrm{SG}=$ singularra; $\mathrm{SUBJ}=$ subjuntiboa; 1 = lehenengo pertsona; 2 = bigarren pertsona; 3 = hirugarren pertsona. 
bat datoz, izan ere, subjektuan betekizun bat ezartzeaz gain, biek ala biek irrealisaren denbora interpretazioa erakusten dute eta menpeko perpausetan azaltzeko ezintasuna.

(7) *Let them go yesterday!

utzi haiei joan atzo

'*Utzi atzo joaten!'

(8) *John ordered let them go!

Johnek agindu zuen utzi haiei joan

‘*Johnek agindu zuen utzi haiei joaten!'

Euskaraz ere antzera jokatzen dute 2. pertsonako aginte perpausek eta 3. pertsonakoek, bai denbora interpretazioan (9), bai menpeko perpausetan azaltzeko ezintasunean $(10)$.

(9) a. *Joan atzo!

b. *Joan bitez atzo!

(10) a. *Jonek agindu du joan zaitez!

b. *Jonek agindu du joan bitez!

Bestalde, Aikhenvald-ek (2010 apud Alcázar \& Saltarelli, 2014, 23) erakusten du benetako aginte perpausen subjektuak (batez ere mintzakidea singularra denean) ez duela agerikoa izan beharrik munduko hizkuntza gehienetan eta mintzakidearen aipamena faktore pragmatikoei lotuta egon ohi dela: kontrastea markatzearekin, enfasiarekin edo kortesiarekin, adibidez.

Euskaraz ere normalean aginte perpausetako subjektua isildu egiten da, baina agerian ere azal daiteke, eta maiz, kontrastea markatzeko helburuarekin azaltzen da, hain zuzen. Hala, (11b)-k (11a)-rekiko kontrastea erakusten du:
(11) a. Altxa zaitez!
b. Altxa zaitez zeu!

(Sareko Euskal Gramatika)

Horrezaz gain, aginterako adizkiei dagokienez, Alcázar eta Saltarellik $(2014,24)$ adierazten dutenaren arabera, oinarrizko formak izan ohi dira, inflexio maila txikikoak. Askotan aditz erroa besterik ez da azaltzen, bokal edo kontsonante tematiko batek edo aspektu morfema batek lagunduta batzuetan. Hala gertatzen da gazteleraren (12a) eta euskararen (12b) kasuan, besteak beste:

$$
\begin{array}{cl}
\text { (12) a. iSal! } \\
\text { irten.AGN } \\
\text { 'Irten!' } \\
\text { b. Etor(ri)! }
\end{array}
$$

(Alcázar \& Saltarelli, 2014, 24)

Aditz jokatugabeaz baliatu beharrean, jokatua erabiliz gero, euskaraz hiru argumenturekiko komunztadura adieraz daiteke aginterako aditzean, beste aditz moduetan gertatzen den bezala: 
(13) Eman iezaiozu!

3SG(ABS).3SG(DAT).2SG (ERG).AGN

(Alcázar \& Saltarelli, 2014, 25)

Hori dela eta, Alcázar eta Saltarellik $(2014,25)$ diotenez, euskara bezalako hizkuntzetako aginte adizkien konplexutasunak kontraste handia erakusten du aditz erro soila bezalako formak baliatzen dituzten hizkuntzetako aginterarekin, eta erakusten du aginterako aditz formak ez direla esan izan dena bezain sinpleak. Nolanahi ere, aipatzekoa da euskaren kasuan ere, komunztaduraren aberastasuna alde batera utzirik, beste aditz moduetan agertzen den erroaren aurreko markarik ez dagola aginte adizkietan.

\section{EUSKAL AGINTERAREN EZAUGARRIAK}

Euskarazko aginte adizkiek, gainerako adizkietatik bereizten dituzten ezaugarriak dituzte. Hori dela eta, badirudi «nolabait esatearren, eskematik kanpo» geratzen direla (Euskaltzaindia, 1987, 33). Adizki hauen berezitasunek modu, pertsona eta denborare$\mathrm{kin}^{3}$ dute zerikusia.

Komunikazioaren ikuspegitik, aginterazko hizketa-ekintzak hiru egoera pragmatiko biltzen ditu: aginte hutsa, eskaera eta aholkua. Aginte mota zehazteko, intonazioaz gain, zenbait adberbio edo postposizio sintagma erabil daitezke euskaraz, mesedez, bestela eta gero bezalakoak, besteak beste.

(14) a. Jarri hemen, mesedez. (Eskaera)

b. Alde egin hemendik, bestela... (Mehatxua)

c. Ez ahantz, gero! (Aholkua)

(Euskaltzaindia, 1987, 8)

Ezin ahaztu dezakegu agintzearen hizketa-ekintzak baldintza pragmatiko jakinak eskatzen dituela sozialki onartua izan dadin, eta ondorioz, hiztunak maiz agerian utzi behar du ez dela agindu bat ematen ari, eskaera bat egiten baizik. Horretarako, intonazioaz gain, leungarri deritzen adberbioak erabili ohi dira: mesedez, arren, otoi... (De Rijk, 2008, 580).

Gero adberbioari dagokionez, aholkua adierazten duen partikula gisa jokatzen du aginterako perpausetan eta desirazkoetan. De Rijk-en $(2008$, 581) arabera, perpaus jokatugabeetan soilik azal daiteke eta ezezko perpausetan ezeztapenaren ondotik agertu ohi da (15a), beste kokaleku batzuk ere har ditzakeen arren $(15 \mathrm{~b}, \mathrm{c})$. Baieztapenetan

3 Egun halakorik ez badago ere, euskara zaharrean badirudi bazegoela geroaldiko agintera, hizkuntzatik desagertu zena:

(i) a. «Paillardiza higuinari egiokek ihesa/ Guztiz ere ez desira lagunaren esposa»

(Etxeberri, Manual debozionezkoa, 173)

b. «Ofensatzen naizenean, finean, garazia/ Indakezu pairatzeko bidegabe handia»

(Etxeberri, Manual Debozionezkoa, 904)

Geroaldiko adizki horiek, -ke- artizkia hartzen zuten (Euskaltzaindia, 1987, 353). 
ere azaltzen da (15d), normalean amaieran. Jokatutako perpausei dagokienez, (15e)-n, De Rijkek dio hiztun batzuek soilik onartzen dituztela. Kasu guztietan intonazio berezia eskatzen du.

(15) a. Ez gero niri gezurrik esan.

b. Ez niri gero Donostia ukitu!

c. Nor denik ez esan gero!

d. Kontuan hartu, gero!

e. Kontuz ibil zaitez, gero!

Aginte perpausetako aditzei dagokienez, adizki analitikoez (16a) edo sintetikoez (16b) balia gaitezke, edo baita aditzoin (edo partizipio) hutsaz (16c) ere.

(16) a. Etor zaitez hona!

b. Zatoz hona!

c. Etor(ri) hona!

Adizki analitikoak sortzeko aditz laguntzaileei dagokienez, "edin ${ }^{4}$ darabilgu aditz iragangaitzekin. Bestalde, aditz iragankor eta ditrantsitiboetarako laguntzailearen hautaketan, aldiz, mikroaldakortasuna dago: "ezan ekialdean eta erdialde gehienean -garai batean orokorra zena (Mitxelena, 1960) eta euskara baturako onartu dena- eta egin mendebaldean (Hualde, Oyharçabal \& Ortiz de Urbina, 2003, 232). Bestelako adizkiekin gertatzen den bezala, "edin eta "ezan laguntzaileekin batera agertzen diren aditz nagusien aspektua ez da agerian markatzen, aditzoina azaltzen da-eta. Hala ere, aginteratik kanpo legez, ez dute berdin jokatzen ekialdeko eta mendebaldeko hizkerek (Euskaltzaindia, 1987, 352; Etxepare, 2003, 529), hortaz, ekialdean aditzoina agertzen den lekuan, erdialdean eta mendebaldean partizipioa dago, bai forma analitikoetan (17), bai aditz jokatugabeko aginteran ere (18):
(17) a. Sar hadi!
b. Sartu hadi!
(18) a. Sar!
b. Sartu!

Morfologiaren aldetik, zenbait aditzek forma sintetikoak badituzte ere, «normalean *edin eta *ezan aditz laguntzaileez baliatzen gara, gure aginteak, erreguak edo aholkuak adierazteko orduan» (Euskaltzaindia, 1987, 351). Dena den, Sareko Euskal Gramatikan (hemendik aurrera $S E G$ ) adierazten denarekin bat etorriz, esango nuke aditz laguntzailerik gabeko agintera dela eguneroko jardunean gehien erabiltzen den agintera.

4 Aditz laguntzailearen txandakatzea izan $\mathrm{v}$ *edun formalki aztertu bada ere (euskararako ikus besteak beste Berro, 2015, Kayne, 1993 segituz), oraingoz ez dugu "edin v "ezan-en azterbide formalik. 
Aditzen osaera morfologikoa denaz bezainbatean, aginterako forma analitikoetako laguntzaileek orainaldiko subjuntiboko forma bera dute, baina amaierako - $(e) n$ konplementatzailerik gabe. Hau ikusten dugu *edin-en adizkietan: hadi, zaitez cf. subj. hadin, zaitezen. Horretaz gain, "ezan-en adizki iragankor eta ditrantsitiboetan, osagarri zuzena 3. pertsona denean subjuntiboan azaltzen den $d$ - morfemarik (orainaldiko markarik) ere ez da agertzen, aginteran espero bezala (ezak/n, ezazu, itzazu cf. subj. dezaan/nan, dezazun, ditzazun) (De Rijk, 2008, 572).

Bestalde, adizki sintetikoekin osatutako perpausetan, sarri askotan, doinuak eta hitz ordenak laguntzen dute esanahia behar bezala ulertzen, izan ere, formaz ez dira beste zenbait adizkitatik bereizten. Izan aditzarena ez, beste aditz iragangaitzen aginterako adizki sintetikoak indikatiboko 2. pertsonako orainaldiko adizki berberak dira (Hualde, Oyharçabal \& Ortiz de Urbina, 2003, 520). Hortaz, hurrenkerak eta intonazioak salatzen dute aginteraren aurrean (19) ala adierazpen perpaus baten aurrean (20) ote gauden.

(19) a. Zatoz hobeto prestatuta.

b. *Hobeto prestatuta zatoz.

(20) a. Hobeto prestatuta zatoz.

b. *Zatoz hobeto prestatuta.

Ikus daitekeenez, (19a)-n aginterako forma dugu: aditza hasieran dago eta beheranzko doinu markatua eskatzen du. (20b)-n adierazpen perpausa dugunez, aditza ezin da hasieran agertu, eta horregatik bere ez-gramatikaltasuna. Euskaraz ezin da aditz sintetikorik azaldu perpaus baten hasiera absolutuan, ez adierazpen, ez galde perpausetan eta, horregatik, aditza hasieran agertuko bada, hasierako Foku burura mugitu den Denbora ahulari euskarri fonologikoa emateko beharrezkoa du $b a$ - txertatzea (Ortiz de Urbina, 1989). Aginte perpausa, ordea, salbuespena da, aditza ezein partikularik gabe azaltzen baita hasiera absolutuan.

Adizki sintetikoen osaeran gehiago sakonduz, gainerako aditz moduetan gertatzen den bezala, aginteran ere ez dute berdin jokatzen aditz iragangaitzek eta iragankorrek. Aginterako joko sintetikoa dute egon, ekin, etorri, ibili, eta joan aditz iragangaitzek (Euskaltzaindia, 1987) eta indikatiboko 2. pertsonako orainaldiko adizkietatik bereizten dituen ezaugarri formal bakarra beheranzko azentua da (De Rijk, 2008, 570).

Adizki sintetiko iragankorrei dagokienez, berriz, Oyharçabalek (2003, 280) adierazten du aginteran ezin dela erabili 3. pertsonakoa ez den osagarri zuzena duen adizkirik, hots, (21) adibidekoa bezalakorik. Beraz, 3. pertsonako osagarri zuzena dutenak soilik erabil daitezke aginteran sintetikoki (De Rijk, 2008, 571), hau da, (22) bezalakoak. Dena den, aginteratik kanpo hartzen duten $d$ - marka falta zaienez, eta ondorioz, soilik aditz erroaz eta komunztadura markez osatuta daudenez, zail egiten da argi ikustea ea benetako sintetikoak diren ala laburdura fonologikodun forma analitikoak.

(21) *Naramazu!

(22) Emak! 
Oyharçabalen $(2003,281)$ arabera, berriz, ez dago aditz iragankor sintetikorik aginteran. Hori argudiatzeko, alde batetik, esaten du (21) bezalako adizkiak ezin direla erabili aginteran, eta bestetik, laburpen fonologikodun hainbat adizkik ez duela forma sintetikorik aginteratik kanpo. Alabaina, (22) bezalako adizkiak sintetiko gisa azaltzen dira zenbait gramatikatan (De Rijk, 2008, 571) eta esango nuke aditz berriekin osatutako adizkiak ez direla inoiz halako laburpen mailara iristen (eskia ezak > "eskiak!). Honetaz gain, iruditzen zait kontuan izan behar dugula Lakarra \& Mounolek (2015) Euskara Arkaikoari buruz diotena, hau da, 1400-1600 ingururako «aditz askoren jokabide sintetikoa defektiboa dela. Esate baterako, erakarri, itzuli, jarri, jo, aditzek aginteran baizik ez dituzte gordetzen beren forma sintetikoak (zarriz 'jarri zaitez' Laz, A28, 78, erakarrak Oih Prov 251, jac 'jo zak' IC)", beraz, gaur egun ere forma sintetiko zenbait aginteran bakarrik mantentzea ez litzateke hain arraroa izango. Dena dela, aditz ditrantsitiboen kasuan, komunztadura hiru argumenturekin egiten denean zail da sintetikoa edo forma analitiko laburtua den erabakitzen, aditz erroari itsatsirik agertzen diren marka berberak ezeztapenarekin batera ahoskatzen baititugu ezezko perpausetan (ekarriozu > eziozu ekarri) eta ez baitute aditz berriekin baino laburpen maila altuagoa erakusten (inprimatu iezaiozu > inprimatuiozu cf. ekarriozu).

Aginte adizkien kokalekuari begiratuz gero, hasierako gunean agertu ohi dira, baina hau ez da nahitaezko baldintza. De Rijkek (2008, 575), aginte adizkiak beste kokaleku batzuetan ere azal daitezkeela erakusteko, (23)-ko adibidea ematen du, besteak beste:

De Rijkek dioenaren kontra, ez dirudi (23), subjektuaren ostean etenik egin gabe behintzat, gramatikala izan daitekeenik. Izan ere, aginte adizki sintetikoa darabilten perpausek, indikatiboko forma bera edukitzean, aditzaren beheranzko intonazioaz gain, subjektuaren ondoko eten bat eskatzen dute aginte perpaus gisa ulertuko badira. Horregatik, adizki sintetikoa analitikoarekin ordezkatuz gero, perpausa hobetu egiten da:

(24) Zu isilik egon zaitez, Lierni!

Hortaz, datu hauek erakusten dute aginte adizkia sintetikoa edo analitikoa izan, perpausean edozein lekutan agertzeko askatasun gutxiago edo gehiago izango dutela.

Aginterako adizki sintetikoek jasaten dituzten murriztapenez ari garela, aipatu beharreko beste ezaugarri berezi bat ezezko perpausetan azaltzeko ezintasuna da.

(25) a. Zatoz gurekin!

b. *Ez zatoz gurekin!

Beraz, ezeztapena eta agintera biak batera gerta badaitezke ere, adizki sintetikoekin ezin da ezeztapenik egin (Etxepare, 2003, 520). (25b)-ri erreparatuz gero, ikus dezakegu adierazpen perpausen kasuan adizki sintetikoek kokaleku sintaktiko hori bera hartzen dutela, ezeztapenaren buru funtzionalarekin bat eginez, eta hortaz, 
badirudi (25b) ezin dela aginterako perpaus gisa interpretatu, lehen esan bezala, formaren aldetik ez baitago halako adizki sintetikoak indikatibokoetatik bereizterik. Ezeztapena aurrera joango bada, adizkera aldatu beharra dugu: edo forma analitikora jo, (26a)-n bezala, edo laguntzailerik gabeko aditzaz baliatu behar gara, (26b)-n bezala. Azken estrategia hori da, hain zuzen, SEGren arabera hizkera arruntean maizenik gertatzen dena:

\section{(26) a. Ez zaitez gurekin etor(ri)! \\ b. Ez etor(ri) gurekin!}

Dena den, euskalkien artean aldeak daude ezeztapeneko aginte perpausetan. Ekialdean (26a) modukoak, SEGk dioenez, "gogor egiten dira belarrirako, latzegiak edo", eta horien ordez, (27a) bezalakoak darabiltzate; aginteraren ordez, optatibo edo desirazko deritzenak, beraz. De Rijk-ek $(2008,577)$ adierazten du desirazkoez gain, ekialdean aditzoin soila ere, (27b)-koa bezalakoa, badarabiltela ezezko perpausetan:

(27) a. Ez zaitezela gurekin etor.

b. Ez etor gurekin.

Ezezko perpausetako -(e)la atzizkiaren erabilera ez da ekialdera mugatzen, halakoak erdialde eta mendebaldean ere erabiltzen baitira. Alabaina, SEGren arabera, semantikari begiratuz gero, -(e)la gabea eta - (e)la-duna «adiera desberdineko perpausak direla ematen du»: lehenbizikoa benetako agindua da eta bigarrenak, berriz, erregu edo agian aholku kutsua du. Dena dela, ekialdeko hizkeretan ezeztapena aditz jokatuaren bidez egiteko bide bakarra hau denez gero, pentsatzekoa da murriztapen sintaktikoren bat dagoela ez duena ezeztapena eta agintera batera gertatzen uzten. Hau da, forma sintetikoekin hizkera guztietan dagoen murriztapena, ekialdean forma analitikoekin ere gertatzen da, eta ondorioz, bestelako bide bat hartu behar dute ezeztapenean.

Hartara, hizkeren arteko desberdintasun nabarmenena, gertakari honi dagokionez, sintaktikoa dela esan dezakegu, kasu hauetan mendebalde eta erdialdeko hizkeretan ez dagoen konplementatzaile bat baitago ekialdeko hizkeretan.

Aginte perpausetako subjektuei erreparatuz gero, agintera kanonikoari dagozkion adizkiak 2. pertsonakoak bakarrik diren arren, berorika mintzatzean, nahiz semantikaren aldetik 2. pertsonakoak izan, morfologia aldetik 3. pertsonakoak diren markak erabili behar ditugu. Adizki hauek, hortaz, agintera arruntak bezala jokatzen dute, subjektu gramatikalak diskurtsoko mintzakidearekin bat egiten baitu, eta aldi berean, hizketa-ekintzaren berariazko egilearekin.

(28) a. Adi beza, jauna, nik esaten diodana.

b. Adi dezala, jauna, nik esaten diodana.

Adizki hauek [subjunktiboa + -(e)la] erakoen baliokide direla ematen duen arren, SEGren arabera, (28a) bezalako egiturak benetako agintera izango dira errespetuzko solasean, eta ezin dira (28b) moduko egiturekin ordezkatu. 
Berorika mintzatzean erabiltzen direnak alde batera utzita, bi erabilera mota bereizten ditu De Rijkek (2008): alde batetik, berariazko egile eta diskurtsoko mintzakide berberak dituena baina subjektu gramatikala beste bat duena legoke (29a); eta bestetik, berariazko egile eta mintzakide desberdinak dituena (29b):

(29) a. Zure hitza ere betor bat haienarekin.

b. Barka biezat Aita Barandiaranek.

(De Rijk, 2008)

Adizki hauen bidez, SEGk dioenez, agindua baino gehiago, hiztunaren desio bat adierazten dela dirudi eta hiztunaren desio hori beteko duena ez da mintzakidea, hirugarren pertsona bat baizik. Mintzakide zehaztugabeko bati zuzendu ohi zaio, ez hiztunak ez mintzakideak bete behar ez duten desio edo erregu bat adieraziz. 3. pertsonako subjektua duten aditz hauek, aginterakoak baino indar modal handiagoa dute (De Rijk, 2008, 582) eta ezaugarri morfologikoei dagokienez, hasieran $b$-morfema dutela ikus dezakegu. Oyharçabalek (2000) erakutsi zuen ziurrenik hasierako morfema hori jatorriz konplementatzaile bat dela, eta ondorioz, perpaus hauek, desirazkoak bezala, eta agintera kanonikoarekin kontrastean, itxuraz soilik direla perpaus beregainak. Oyharçabalek $(2003,282)$ ohartarazten duen moduan, $d$-, $z$ - eta $l$-aurrizkiekin batera, $b$ - ere denbora-modu morfema gisa analizatu izan bada ere, $b a$ - edo bait- konplementatzaileen antza handiagoa du jokaera sintaktikoari begiratuz gero, izan ere, adizki hauek ezin dira alokutiboak izan ("Betorrek hire laguna vs. Betor hire laguna) eta ezin dute beste ezein konplementatzaile hartu ("betorrela vs. datorrela). Hala ere, semantikaren aldetik, aginte perpausek ere desirak eta aholkuak adierazi ditzaketenez, 2. pertsonako aginte perpaus kanonikoen eta perpaus hauen artean, desberdintasun kuantitatiboa dagoela esan liteke.

Adizki hauen osaerari dagokionez, $b$ - konplementatzaileak aginteran espero ez dugun $d$ - denbora aurrizkiaren lekua hartzen du. Gainerako zatia ez da indikatiboarenetik bereizten adizki sintetikoen kasuan eta forma analitikoetako laguntzailearen kasuan, subjuntiboaren amaierako -(e)n-a falta du.

Ezeztapenari so eginez gero, aginterarekin gertatzen den gauza bera topatzen dugu adizki hauetan, sintetikoekin bateraezinak direla, alegia; eta ondorioz, adizki analitikoetara jo behar dugula ezeztapenean.

(30) a. Bihoa sukaldera. (vs. *Ez bihoa sukaldera)

b. Ez bedi sukaldera joan.

Beraz, 3. pertsonako subjektua duten perpaus hauetan aginteran ikusten dugun murriztapen bera ikusten dugu. Esan beharra dago, dena den, $b$ - morfemadun adizki hauen erabilera oso bakana dela egungo ahozko euskaran, berorikaren erabilera bera geroz eta murritzagoa izaki. Adizki hauen berorikaz kanpoko erabilerari buruz ere gauza bertsua esan daiteke, oso egoera diskurtsibo jakinetara mugatzen baita, batez ere diskurtso erlijioso edo testu oso formaletara. 
Aginte perpaus ez-kanonikoez (hau da, 2. pertsonakoa ez den beste subjektu bat dutenez) ari garela, 1. pertsona plurala (31) eta singularra (32) ere erabil ditzakegu, eta hauekin ere subjuntiboa darabilgu, forma sintetiko zein analitikoekin.

(31) a. Goazen hemendik!

b. Kanta dezagun elkarrekin!

(32) a. Noan arineketan.

b. Sar nadin etxean.

Hartzen duten konplemetatzaileari so eginez gero, 3. pertsonarekin -(e)la darabilgula ikus dezakegu eta 1. pertsonarekin, berriz, -(e)n konplementatzailea. 1. pertsonarekin -(e) $n$ konplementatzaileaz gain, -(e)la ere erabil dezakegun arren, SEGren arabera, bigarrenak erregu kutsu handiago du.

\section{(33) a. Ez gaitezen bidean gal. \\ b. Ez gaitezela bidean gal.}

SEGren arabera, (33b)-ko perpausak (33a)-koak baino erregu kutsu handiagoa du, -(e)la konplementatzailedun perpausen eta 2. pertsonako aginte perpausen artean gertatzen den moduan. Beraz, desberdintasun kuantitatiboa genuke berriro ere.

\section{AGINTERAKO SUBJEKTUA. HIZKUNTZA ALDAKORTASUNA}

\subsection{Aginterako azaleko subjektua mintzakidea denean}

Ingelesa hartzen dute Mauck-ek eta bestek (Mauck, Pak, Portner \& Zanuttini, 2005) mintzakideari edo mintzakidea barnean duen talde bati zuzendutako agintera soilik onartzen duten hizkuntzen adierazgarri. Honelako hizkuntzetan, mintzakidea eta azaleko subjektua bat etorri behar dira eta, subjektuak nolabaiteko egile ${ }^{5}$ rol tematikoa izan behar duela esan liteke (ibid., 2).

(34) $\varnothing$ eat your dinner!

jan zure afaria

'Afal ezazu!'

5 Egile diodan arren, kontuan izan behar da aginterako subjektu guztiek ez dutela egile rol tematikoa:

(i) a. Egon hemen!

b. Ez sufritu horregatik!

Horregatik, Mauckek eta bestek $(2005,2)$ agent beharrean agentive izena darabilte subjektu hauen rola izendatzeko, eta Alcázar eta Saltarellik (2014), berriz, performer. Lan honetan zehar, terminologia horren faltan, aginte perpausetako subjektuen rolaz hitz egitean egile izena erabiliko dut, kasu batzuetan benetako egilea izango ez den arren, baizik eta predikatuak adierazten duena bete behar duena, gauzatzaile-edo dei dakiokeena. 
(34) adibideko Ø elementuak hiru ezaugarri hauek ditu (Mauck et al., 2005): lehenik, subjektuaren gunean dago; bigarrenik, mintzakideari egiten dio erreferentzia eta hirugarren eta azkenik, egile bezala interpretatzen da.

Bestalde, ingelesezko aginterari buruzko literaturan, (35) bezalako adibideak azaltzen dira (Postdam, 1998 apud Zanuttini, 2008), mintzakideak eta subjektuak bat etorri gabe agertzeko gaitasuna erakusten duten agindu perpausen adibide gisa.

(35) Nobody leave the hall, sergeant!

inor.ez utzi ART gela sarjentu

'Ez dadila inor gelatik irten, sargentu!'

(Zanuttini, 2008)

Alabaina, Zanuttinik $(2008,207)$ adierazten du kontsultatu dituen hiztun gehienek ez-gramatikaltzat jotzen dituztela (35) bezalako perpausak.

\subsection{Aginterako sakoneko subjektua mintzakidea edo hiztuna izan daitekeenean}

Hizkuntza batzuetan, sanskritoa kasu, azaleko subjektuak ez du mintzakidearekin bat etorri beharrik 3. pertsonako agintera pasiboa dutelako. Hala, 3. pertsonako agintera erabiltzen den kasuetan, mintzakidea ez da azaleko subjektua, bai, ordea, egilearen rol tematikoa duena (Mauck et al., 2005). Honez gain, sanskritoak aginterako paradig$m a^{6}$ osoa du, hau da, ohiko 2. pertsonako agintera eta 3. pertsonako agintera pasiboaz gain, 1. pertsona singularreko eta pluraleko agintera ere baditu. Hori dela eta, halako hizkuntzetan zaila da 2 . pertsonako agintera beste aginte perpausetatik bereiztea.

\subsection{Aginterako subjektua mintzakidea edo hiztuna ez den beste bat izan daitekeenean}

Beste hizkuntza batzuetan, aginte perpausaren mintzakide edo hiztunak ez du subjektuarekin bat etorri beharrik. Bhojpurierak ${ }^{7}$, esaterako, aginterako aditz paradigman 1., 2. eta 3. pertsonako formak ditu. Subjektua eta mintzakidea bat ez datozen kasuetan, dena den, mintzakidea subjektuaren gainean eragiteko ahalmena duen norbait izan behar da.

\subsection{Tarteko ondorioak}

Badirudi ingelesa bezalako aditz morfologia urriko hizkuntzek murriztapen gehiago jasaten dituztela aginterako subjektuaren aukeraketan morfologia aberatsa duten bhojpuriera bezalako hizkuntzek baino. Halere, aipatzekoa da ingelesezko (35) bezalako perpausak hiztun batzuek onartzen dituztela eta, beraz, esan genezake hizkuntzen barnean ere mailaketa egon litekeela 2. pertsonaz kanpoko subjektua duten perpausen onargarritasunean (Mauck et al., 2005, 7). Kontuan izan behar da, dena den, aginterarako

6 Paradigma izena darabilt Maucki et al.-i $(2005,8)$ jarraituz.

7 Bhojpuriera India iparraldean eta Nepal hegoaldean hitz egiten den hizkuntza indoariarra da (Lewis, Simons \& Fennig (arg.),2016). 
paradigma osoa erakusten duten hizkuntzak oso gutxi direla eta hizkuntza gehienek 2. pertsonara mugatzen den agintera defektibo bat erakusten dutela ${ }^{8}$.

Alabaina, aginterarako eta hortatiboetarako ${ }^{9}$ paradigma bera duten hizkuntzak egoteak iradokitzen du talde gisa aztertu behar direla. Gainera, badirudi ingeles zaharrean, gaztelania zaharrean eta euskara zaharrean, besteak beste, hortatiboak sintetikoak zirela (Visser, 1966, Azkue, 1925 apud Alcázar \& Saltarelli, 2014, 37), egungo aginte formen modukoak, alegia.

Horrez gain, hortatiboek aginteraren ezaugarri garrantzitsuenak dituzte: ezin dira menpeko perpausetan azaldu, irrealisen interpretazioa dute eta ekintza kontrolatuetara mugatzearen murriztapena erakusten dute (Alcázar \& Saltarelli, 2014, 38).

Hortatiboen eta aginteraren arteko desberdintasun semantikoari dagokionez, desberdintasun kuantitatiboa ikusten dute Alcázar eta Saltarellik (2014, 40). Izan ere, 3. pertsonako hortatiboek desirak adierazten dituztela esan izan da, baina aginte perpausek ere desirak adieraz ditzakete. Gazteleraz, esaterako, desira bat adierazi daiteke (36a)-ko aginte perpausaz ez ezik, konplementatzailea eta subjuntiboa darabiltzan (36b)-ko egituraz ere, itxuraz, esanahian inolako alderik sortu gabe.

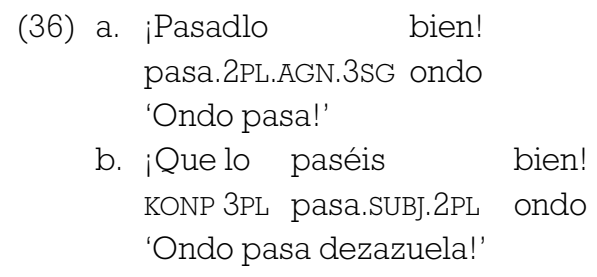

(Alcázar \& Saltarelli, 2014, 40)

Antzekotasun morfosintaktiko eta semantikoetan oinarriturik, hortatiboak agintera arazle edo bigarren eskuko agintera (ingelesez, proxy imperative) direla proposatzen dute Alcázar eta Saltarellik (2014, 41). Proposamen honek, biek partekatzen dituzten ezaugarriak azal ditzake, eta pentsarazten du paradigma desberdina erabiltzearekin batera arazletasuna agerian jartzen dela.

Aginteratik kanpoko paradigma erabiltzen den egituretan, hiztunarekin eta mintzakidearekin batera hirugarren pertsona bat sartzen da jokoan, hots, egilea (ingelesez, performer $)^{10}$.

8 Mauckek (2005 apud Zanuttini, 2008) erakutsi zuen oso hizkuntza gutxik dutela aginterako paradigma osoa. Hizkuntza gehienek 2. pertsonako formak bakarrik dituzte aginteran, hizkuntza batzuek 2. pertsonakoez gain, 1. pertsona pluraleko formak ere badituzte, beste batzuek, 2. eta 3. pertsonako aginterako formak dituzte, eta hizkuntza gutxi dira paradigma osoa dutenak.

9 Alcázar eta Saltarellik (2014) hortatibo (ingelesez, hortative) izena ematen diete 1. eta 3. pertsonako subjektua duten aginte perpaus ez-kanonikoei.

10 Egile hitza erabili dut ingelesezko Alcázar eta Saltarellik (2014) darabilten performer itzultzeko, nahiz eta, 4.1 atalean azaldu dudan moduan, aginterako subjektu orok ez duen egile rola. Ikus 5. oin-oharra. 
1. taula. Aginterako egile motak (Alcázar \& Saltarelli, 2014, 123)

\begin{tabular}{|c|c|c|l|}
\hline Hiztuna & Mintzakidea & Egilea & \multicolumn{1}{|c|}{ Aginterako perpausa } \\
\hline A & B & B & Go! 'Joan!' \\
\hline A & B & C & Let him/her/them go! 'Joan dadila!' \\
\hline A & B & A & Let me go! 'Joan nadin!' \\
\hline A & B & A + B & Let... go! 'Joan gaitezen!' \\
\hline
\end{tabular}

Beraz, aginte perpaus kanonikoetako mintzakidea ekintzaren berariazko egilea da eta perpaus ez-kanonikoetan, berriz, eragilea. Desberdintasun honek, nola ez, sintaxian izango du isla ${ }^{11}$.

\section{EUSKAL AGINTERAREN SINTAXIA INGELESAREN ANALISI SINTAKTIKOAREN ARGITAN}

Ingelesa ez da subjektu isileko hizkuntza (Duguine, 2010), eta, hala ere, aginteran isileko subjektua onartzen du. Hau azaltzeko, Zanuttinik (2008) aginterako perpausetan beste perpaus batzuetan ez dagoen islapen funtzional bat dagoela proposatzen du, hots, Sintagma Jusiboa (ingelesez, Jussive Phrase).

Aginte perpausetako subjektuari dagokionez, literaturak bi agintera mota bereizi izan ditu: alde batetik, berariazko egilea den mintzakideari zuzentzen zaiona (37a), eta bestetik, berariazko egilean eragiteko gai den mintzakideari zuzentzen zaiona (lehen (35) bezala azaltzen zena eta orain (37b)-n errepikatua).

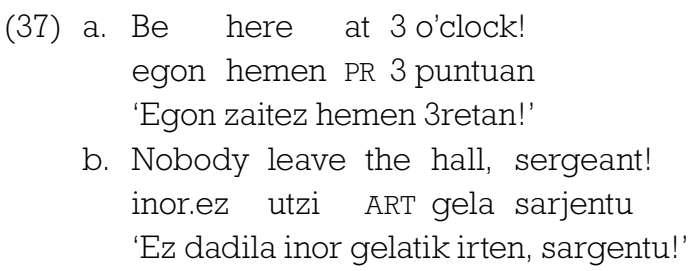

4. atalean azaldu dudan bezala, (37a) bezalakoak dira ingeles hiztun guztiek onartzen dituztenak, eta honelako subjektu isileko aginte perpausak dira, halaber, hizkuntza guztietan onartzen direnak. (37b) bezalako perpausak ingeles hiztun batzuek bakarrik onartzen dituzte, eta halakoak hizkuntza askotan (guztietan ez bada ere), aginteraz besteko paradigmetako aditzak darabiltzaten perpausen bidez adierazten dira.

11 Agintera kanonikoen eta ez-kanonikoen egitura sintaktikoak bereizten dituen proposamen baterako, jo bedi Alcázar eta Saltarelliren $(2014,124)$ lanera. 
Aginte adizkien paradigma mugatua izatea ez da arraroa munduko hizkuntzetan zehar, eta Zanuttinik $(2008,188)$ adierazten du aginte adizkien paradigma morfologikoa forma bakarrera mugatuta duten hizkuntzetan, ingelesean kasu, isileko subjektua 2 . pertsona gisa interpretatzen dela beti.

Beraz, aginte perpausetako mintzakidearen eta subjektuaren artean erlazio berezi bat dagoela dirudi. Erlazio hau azaltzeko, Zanuttinik (2008) proposatzen du Sintagma Jusiboak 2. pertsonaren ezaugarriak dituela eta islapen funtzional honen bidez, aginteraren egitura sintaktikoak mintzakidearen nozioa kodetzen duela.

Mintzakidea eta subjektua bat etortzen ez diren perpausetan, hizkuntza gehien gehienetan aditzak jokatua izan behar du, eta horrek esan nahi du hizkuntza hauetan behintzat pertsona ezaugarriak dituen islapen bat dagoela nahitaez. Hau ikusirik, Zanuttinik proposatzen duena da (37b) bezalako perpausetan ere pertsona ezaugarriak dituen islapen bat dagoela, eta islapen hau dela, hain zuzen ere, subjektuari kasua eman eta Sintagma Jusiboaren eta subjektuaren arteko komunztadura oztopatzen duena.

Izan ere, Zanuttiniren (2008) arabera indar direkzionala (ingelesez, directive force) duten perpaus guztietan dago Sintagma Jusiboa. Islapen honek operatzaile bat du bere espezifikatzailean, lambda operatzaile bezala jokatzen duena. Horrez gain, Sintagma Jusiboak pertsona ezaugarriak ditu, eta ondorioz, subjektutik hurbilen dagoen eta pertsona ezaugarriak dituen elementua hau denean ((37a) bezalako aginte perpaus kanonikoetan gertatzen den moduan), Sintagma Jusiboko buruak komunztadura egiten du subjektuarekin eta 2. pertsonako ezaugarriak ematen dizkio. Aldiz, Sintagma Jusiboaren eta subjektuaren artean pertsona ezaugarriak dituen beste elementu bat dagoenean ((37b) bezalako aginte perpaus ez-kanonikoetan) ezin da komunztadurarik gertatu.

Zanuttinik (2008) honako egitura sintaktikoa proposatzen du:

(38)

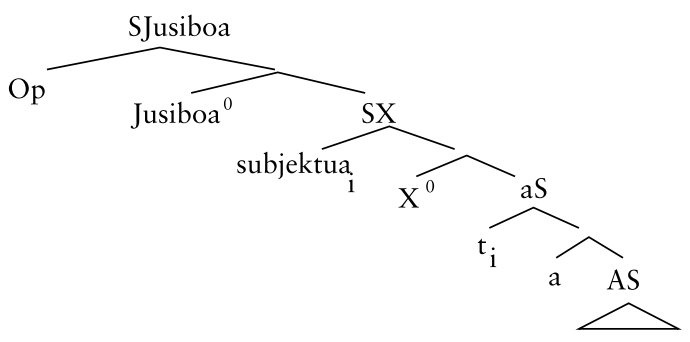

Euskara itzuliz, 3. pertsonako subjektua duten aginte perpausak aztertzen baditugu honako hau ikusten dugu:

(39) a. Margotu paisaia!

b. Margotu bezate paisaia umeek, maisu!

c. Margotu dezatela paisaia umeek, maisu! 
Beraz, subjektua zein den jakiteko komunztadurari begiratzerik ez dugunean, (39a)-n bezala, subjektua beti da 2. pertsonakoa. Gainera, (39b,c)-n ikusten den moduan, izan $b$ - morfemadun adizkiaren ${ }^{12}$ bidez (39b), izan subjuntiboaren bidez (39c), aginteratik kanpoko adizkiak erabiltzeaz gain, aditzak jokatua izan behar duela ikus dezakegu.

Zanuttitiren (2008) proposamenarekin lotuz, beraz, badirudi 3. pertsonako subjektua duten perpaus hauetan subjektuaren eta Sintagma Jusiboaren artean pertsona ezaugarriak dituen islapen bat dagoela eta islapen hau dela bien arteko komunztadura galarazten duena.

Ingelesez aginte perpausetako subjektu izan daitezkeenak aztertzen baditugu, ikus dezakegu ageriko izenordaina erabiliz gero, 2. pertsonakoa bakarrik ager daitekeela, (40a)-n bezala, eta (37b) modukoak gramatikalak diren hiztunentzat ere, (40b) adibidea ez-gramatikala da.

$$
\begin{aligned}
& \text { (40) a. You do it! } \\
& \text { zuk egin hori } \\
& \text { 'Zuk egin hori!' } \\
& \text { b. *He do it! } \\
& \text { hark egin hori } \\
& \text { '*Hark egin hori!' }
\end{aligned}
$$

Zanuttiniren $(2008,190)$ arabera, honek erakusten du arazoa ez dela semantikoa, sintaktikoa baizik.

Ingelesezko aginte perpausetako subjektuekin jarraituz, subjektu kuantifikatzaileei dagokienez, bestelako perpausetan ez bezalako jokaera erakusten dute aginteran, izan ere, (41)-ren interpretazioan, subjektuak mintzakide multzoa barnebildu behar du.

(41) Everybody do your homework!

denek egin zuen etxeko.lanak

'Egin itzazue denek zeuen etxeko lanak!'

Adierazpen eta galde perpausetan, berriz, mintzakidea barnean har badezake ere, ez da derrigorrezkoa. Euskaraz ere gauza bera gertatzen da:

(42) a. Egin itzazue denek zeuen etxeko lanak!

b. Egin denek zeuen etxeko lanak!

c. Denek egin dituzue (/dituzte) etxeko lanak.

12 Adizki hauek jusibo izenez azaltzen dira zenbait euskal gramatikatan (De Rijk, 2008; Hualde \& Ortiz de Urbina, 2003), baina Sintagma Jusiboarekiko nahasmena saihestu asmoz, $b$ - morfemadun aginterako adizki deitu diet. 
Aditz jokatua duen (42a) perpausean bezala, jokatugabea den (42b) perpausean ere, interpretazio bakarra da mintzakide multzoa barnean hartzen duena. (42c)-n ordea, adierazpen perpausa izanik, izenordain kuantifikatzaileak ez du zertan diskurtsoko mintzakidea barnebildu.

Uztardura aukerei dagokienez, bestalde, aginterako subjektu kuantifikatzaileak 3. pertsonako izenordain eta anaforekin ez ezik, 2. pertsonakoekin ere uztar daitezke ingelesez. Adierazpen eta galde perpausetan, ordea, 3. pertsonako izenordain eta anaforekin bakarrik uztar daitezke, (43b)-n ikus daitekeen moduan. Kontuan izan behar da, gainera, (43a) bezalako perpausetan, 3. pertsonako izenordainak erabilita ere, mintzakidea hartzen dutela beren barruan.

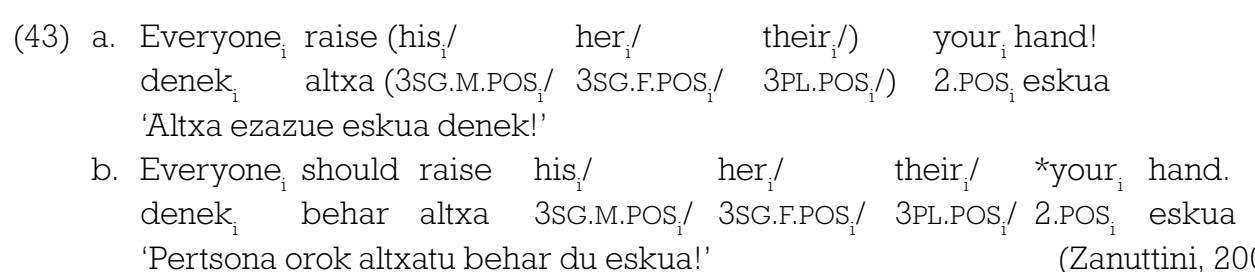

Euskarazko kuantifikatzaileei erreparatuz ikus daitekeenez, kuantifikatzaile gehienekin, (44a) bezalako 3. pertsonako izenordaina duten aginte perpausak ez dira posible, 2. pertsonako izenordainak soilik erabil baitaitezke.

(44) a. * Jaso denek beren eskua!

b. Jaso denek zeuen $_{i}$ eskua!

Gainerakoan, ingelesezko aginteran, izen bereziak ere izan daitezke perpausaren subjektuak. Halakoak juntadura egituretan gertatzen dira eta mintzakideen multzotik norbanako batzuk aukeratzen dituzte.

(45) John $n_{i}$ raise your ${ }_{i}$ hand, Mary wiggle your $_{j}$ fingers! John altxa zure eskua Mary mugi zure hatzak John, altxa zure eskua; Mary, mugi zure hatzak!

(Zanuttini, 2008)

Izen bereziek aginterako perpausetan 2. pertsonaren ezaugarriak erakusten dituzte, interpretazioan bezala, baita uztardurari dagokionez ere. Aginteran soilik da posible (45)-n ikusten den moduko izen berezien eta 2. pertsonaren arteko uztardura.

Euskarari dagokionez, ez dirudi izen bereziek aginterako subjektu izateko gaitasuna dutenik. Ezintasun hau hobeto antzematen da aditz iragankorra duten (46b) bezalako perpausetan, aditz iragangaitza duten (46a) bezalakoetan baino. Izan ere, diskurtsoaren etena eskatzeaz gain, argi ikusten da izen bereziok ez direla perpauseko argumentuak ergatibo markarik ezak erakusten duenez. Hain zuzen ere, ergatiboa erabiliz gero, perpausa ez gramatikala bihurtzen da (46c) ikusten den bezala. Hortaz, izen bereziak euskaraz behintzat ezin dira aginte perpausetako subjektu gisa erabili, bokatibo bezala baizik. 
(46) a. Zatoz hona, Jon; zoaz hara, Ana.

b. Jaso zure eskua, Jon; mugi zure hatzak, Miren!

c. *Jaso zure eskua Jonek; mugi zure hatzak Mirenek!

Aginterako subjektuekin jarraituz, ingeles hiztun guztiek onartzen dituzte izen biluzi pluralak subjektu gisa. Interpretazioari begiratuz, (47b) bezalako adierazpen eta galde perpausetan ikus daitekeen interpretazio generikoa falta zaie (47a) bezalako aginte perpausetako subjektuei. Gainera, (47c)-n ikus daitekeen bezala, subjektu hauek, kuantifikatzaileek bezala, 2. pertsonako elementuekin egiten dute uztardura, nahiz eta adierazpen eta galde perpausetan 3. pertsonakoekin bakarrik uztartu.

(47) a. Boys be the cops and girls be the robbers! mutilak izan ART poliziak eta neskak izan ART lapurrak 'Mutilak, izan poliziak, eta neskak, izan lapurrak!'

b. Boys love cops and girls are fascinated by robbers. mutilak maitatu.3PL poliziak eta neskak izan.3PL liluratuta PR lapurrak 'Mutilek poliziak maite dituzte eta lapurrek neskak liluratzen dituzte.'

c. Boys $s_{i}$ raise your hands; girls ${ }_{j}$ wiggle your fingers! mutilak altxa zuen eskua neskak mugi zuen hatzak 'Mutilak, altxa eskua; neskak, mugi hatzak!'

(Zanuttini, 2008)

Euskaraz ere gauza bera gertatzen da interpretazioari dagokionez $-a(k)$ mugatzailedun izenak darabiltzagunean. $-a$ eta $-a k$ artikuluak inguruko hizkuntzetakoek baino erabilera zabalagoa dute eta besteek izen biluzi edo artikulu mugagabeak darabiltzaten zenbait testuingurutan agertzen zaizkigu (Etxeberria, 2010; Artiagoitia, 2012). Mugatzaileen interpretazio nagusiak hiru dira: mugatua, generikoa eta existentziala. Aginteran, aldiz, irakurketa bakarra dute, mugatua hain zuzen ere (48a). Izenordainei dagokienez, (48b) adibidean ikus daiteke 2. pertsonakoak bakarrik direla posible, ingelesez bezala. Alabaina, (46)-ko izen bereziekin gertatzen den moduan, kasu markapenari begiratuz, (48)-ko mutilak eta neskak izenak ezin daitezke subjektu gisa analizatu, bokatibo gisa baizik.

(48) a. Izan poliziak, mutilak; izan lapurrak, neskak!

b. Jaso zuen eskuak, mutilak; mugi zuen hatzak, neskak!

c. *Jaso zuen eskuak mutilek; mugi zuen hatzak neskek!

Zanuttiniren $(2008,195)$ arabera, ingelesezko (45) eta (47) adibideetan bokatiboek eskatzen duten intonazioaren etena falta da. Gainera, adibideotan subjektu gisa azaltzen diren izen bereziek eta izen arrunt biluziek mintzakideen multzotik banako bat edo batzuk aukeratzen dituzte, eta bokatiboek, aldiz, multzo osoari egiten diote erreferentzia. (49)-ko kids bokatiboak multzo osoa hartzen du eta etena eskatzen du. Subjektu gisa erabilitako izen bereziek, aldiz, norbanako bat hautatzen dute multzotik eta ez dute etenik eskatzen:

(49) Kids, Gabriel comb your hair; Dani put on your shoes! umeak Gabriel orraztu zure ilea Dani jarri zure oinetakoak 'Umeak! Gabriel, orraztu ilea; Dani, jarri oinetakoak!' 
Beraz, euskarazko aginterako subjektuak ez datoz bat ingelesezko aginterako subjektuekin. Izan ere, hizketa etenak eta, batik bat, kasu markapenak, agerian uzten dute izen bereziek, (46)-n, eta izen arruntek, (48)-n, ez dutela subjektu gisa jokatzen. Euskaraz, hortaz, subjektu isilaz gain, badirudi 2. pertsonako izenordain arrunt zein indartuak ( $h i$, heu, zu, zeu, zuek, zeuek) eta kuantifikatzaileak erabil ditzakegula aginterako subjektu moduan:

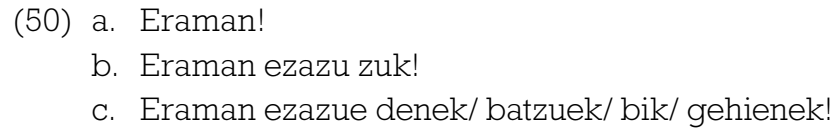

Ingelesezko aginte perpausetako subjektuaren ezaugarri bereziak ikusirik, Zanuttinik (2008) proposatzen du Sintagma Jusiboaren buruak perpauseko subjektuarekin komunztadura harremana edukitzeko bi baldintza bete behar direla: batetik, Sintagma Jusiboa pertsona ezaugarriak dituzten elementuen artean subjektutik gertuen dagoena izan behar da komunztadura harremana eduki ahal izateko; eta bestetik, subjektua era batekoa izan behar da: determinatzailearen posizioa hutsik eduki behar du 2. pertsonako ezaugarriak hartu ahal izateko.

Ingelesari dagokionez, (45) eta (47) adibideetan ikusi dugun moduan, aginte perpausetan izen bereziak eta izen arrunt biluziak ager daitezke subjektu bezala. Izen sintagma hauek ez dute ageriko determinatzailerik, eta beraz, Sintagma Jusiboaren pertsona ezaugarriak determinatzaile geruzan zehar igaro daitezke, honela, aginterako subjektu izatea eta 2. pertsonaren ezaugarriak hartzea ahalbidetuz. Subjektu kuantifikatzaileei dagokienez, Zanuttinik $(2008,199)$ proposatzen du Sintagma Jusiboko buruak sintagma kuantifikatzaileetako $\varnothing$ elementuari 2. pertsonako ezaugarriak ematen dizkiola, subjektu isileko perpausetan gertatzen den bezala.

Euskarari dagokionez, berriz, ingelesez izen arrunt biluziak erabiltzen diren egoeretan (47), euskaraz - ak mugatzailea erabiltzen dela ikusi dugu (48) adibidean, eta mugatzaile hau agertzen duten izenak ezin direla aginte perpauseko benetako subjektuak izan. Gertaera hau ongi ulertzen da Zanuttinik (2008) dioenarekin, izan ere, halakoetan, determinatzaile sintagma mugatuta dagoenez, ez genuke esperoko aginteraren pertsona ezaugarriak bertatik igarotzeko lekua egoterik.

Hiztun batzuek soilik onartzen dituzten ingelesezko (37b) bezalako perpausei dagokienez, Zanuttinik $(2008,208)$ dio benetako aginte perpausekin ezaugarri garrantzitsu bat partekatzen dutela: bietan betekizun bat ezartzen zaio subjektuari. Honek pentsarazten du Sintagma Jusiboa bietan dagoela, subjektua baino goragoko islapen batean, predikatua asetzea eragotziz. Hartara, benetako aginte perpausen eta (37b) bezalako perpausen arteko desberdintasuna ez letorke Sintagma Jusiboaren agertze edo ez agertzetik, baizik eta sintagma buruak bere pertsona ezaugarriak subjektura igarotzeko erakusten duen gaitasunetik, hots, subjektuarekin duen erlazio sintaktikotik. Bestela esanda, Sintagma Jusiboko buruaren eta subjektuaren artean dagoen komunztadura erlazioan datza bi perpaus moten arteko aldea, hau da, benetako aginteran komunztadura erlazioa dago eta (37b) bezalako (orain (51) bezala errepikatuta) aginte perpaus ez-kanonikoetan ez. 
(51) Nobody leave the hall, sergeant! inor.ez utzi ART gela sarjentu 'Ez dadila inor gelatik irten, sargentu!'

(Zanuttini, 2008)

Aginte perpaus ez-kanonikoetan aginteratik kanpoko aditzak erabiltzen dituzten hizkuntzetako adizkiei erreparatuz, adizki jokatuak darabiltzatela azpimarratzen du Zanuttinik $(2008$, 209), eta beraz, pertsona ezaugarriak dituen buru funtzional bat dagoela halako perpausetan. Buru funtzional hau subjektuaren kasu ezarpenaren eragilea izateaz gain, Sintagma Jusiboaren eta subjektuaren arteko komunztadura erlazioa oztopatzen duena dela iradokitzen du Zanuttinik (2008).

Aginte perpauseko subjektuaren eta aditzaren arteko erlazioari dagokionez, Bennisek (2006 apud Zanuttini, 2008) erakusten du nederlanderako aginteran isileko subjektua aditza jokatugabea denean bakarrik erabil daitekeela eta aditza jokatua denean beti ageriko subjektua dagoela. Hau ikusirik, proposatzen du ageriko subjekturik ez dagoenean, 2. pertsonaren ezaugarriak dituen elementu bat dagoela, ez duena ez zenbaki ez formaltasun mailari buruzko zehaztapenik. Hala, aditza jokatugabea izanik, komunztadura erlazioak isileko subjektua egotea ahalbidetzen du. Aditz jokatua darabiltenean, ordea, aditzak zenbakia eta formaltasun maila zehaztuta dituenez gero, beharrezkoa da ageriko subjektua.

Laburbilduz, Zanuttinik (2008) proposatutakoa euskarara ekarri eta Sintagma Jusibo deritzon islapen funtzionalaren bidez euskal aginteraren zenbait ezaugarri azal daitezkeela esan daiteke. Kontuan izan behar da Zanuttinik $(2008,212)$ adierazten duela indar direkzionala erakusten duten perpaus guztietan dagoela Sintagma Jusiboa, eta beraz, aginte adizkiak darabiltzaten perpausetan egoteaz gain, forma osagarriak (subjuntiboa, esaterako) erakusten dituzten perpausetan ere badagoela proposatzen duela. Honek, euskarazko aginte perpaus ez-kanonikoetan ere islapen hau badagoela pentsatzera garamatza.

\section{AGINTERAKO EZEZTAPENEAN SAKONDUZ}

3. atalean esan bezala, aginterako adizki sintetikoak ezin daitezke ezezko perpausetan azaldu:

(52) a. Zatoz gurekin!

b. *Ez zatoz gurekin!

Hala, agintera eta ezeztapena batera agertzen direnean adizki analitikoaz edo aditz jokatugabeaz baliatu behar gara. Dena den, lehen azaldu moduan, ekialdeko hizkeretan -(e)la konplementatzailea azaltzen da horrelako kasuetan:

(53) Ez zaitezela gurekin etor.

Aginterako ezeztapenean ikusten dugun murriztapen honen atzean Postma eta Van der Wurff-ek $(2007,221)$ aginterako ezeztapenari buruz ikertu dutenaren ondorioak 
egon daitezkeela pentsa liteke. Egile hauen arabera, ezeztapen partikula anaforikoa eta perpaus barrukoa desberdinak dituzten hizkuntzetan bakarrik dago benetako agintera ezeztapenean. Aztertu dituzten hogeita hiru hizkuntza erromantze eta germaniarretan banan-banako egokitasuna dagoela egiaztatu dute: perpaus barruko ezeztapen partikula eta anaforikoa ${ }^{13}$ berbera duten hizkuntzek ez dute benetako ezezkako aginte perpausik eta ezeztapenean bestelako estrategiatara jo behar dute (subjuntibora edo infinitibora), eta alderantziz, partikula desberdinak dituzten hizkuntzek, aginte adizkiak darabiltzate ezeztapenean ere (ibid., 227).

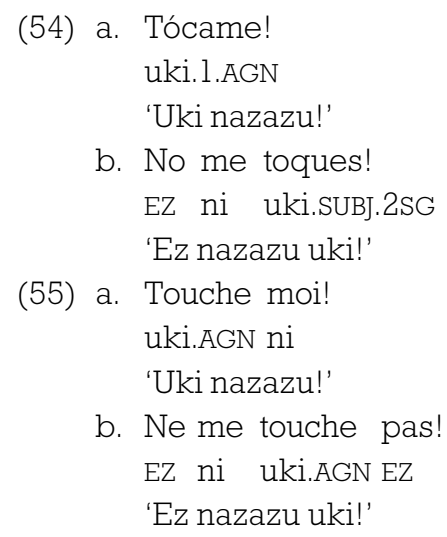

Horren arrazoia, Postma eta Van der Wurffen $(2007,236)$ arabera, sintaktikoa da: aginte aditzak eta ezeztapenak operatzaile gisa funtzionatzen dute, baina, bi ezeztapen mota bereizi behar ditugun aldetik, bakarrak du operatzaile izaera. Hala, bi ezeztapen partikulen arteko aldea A/A' izaera desberdinetik letorke. Ezeztapen anaforikoa eta perpaus barnekoa desberdinak dituzten hizkuntzetan, bi ezeztapenek islapen desberdinak dituzte sintaxian, bata espezifikatzailea da eta bestea burua, hurrenez hurren. Honela, bi ezeztapenak desberdinak diren hizkuntzetan aginterako ezeztapen perpausetan ez dago arazorik aginterako aditza $\mathrm{KONP}^{14}$-era mugitzeko, $\Sigma \mathrm{S}$ saihestuz, A' mugimendua denez gero. Ezeztapen partikula bakarra duten hizkuntzetan, ordea, mugimendu hau ez da posible, izan ere, egitura oztopatuta dagoenez, aditzak ezin du $\Sigma$ S saihestu, eta ondorioz, aginterako ezeztapen perpausak ez-gramatikalak dira.

Postma eta Van der Wurffek $(2007,238)$ ohartarazten dute badirela, dena den, bi multzo hauetan sar ezin daitezkeen hainbat hizkuntza ere. Ezeztapen elementuak aditzean txertatzeko gaitasuna badu eta ezeztapenaren bi islapenak lot badaitezke aditzaren

13 Postma eta Van der Wurff-ek (2007) ezeztapen anaforikoa deitzen diote perpausa ezeztatzeko erabiltzen den ezeztapenari (adibidez, ingelesezko no-ri) eta perpaus barneko ezeztapena perpaus barnean agertzen denari (ingelesezko not-i, esaterako).

14 Zanuttinik (2008) Sintagma Jusibo deitzen dionari Postma eta Van der Wurffek (2007) KONPS deitzen diote. Beraz, 6. atalean KONP gisa azaltzen dena eta gainerako ataletan ageri den Sintagma Jusiboaren burua gauza bera da. 
mugimendua zilegi da. Lotura hori gabe aditzak ezingo lituzke bi ezeztapen buruak zeharkatu, eta beraz, KONP-erako buru mugimendua ez litzateke posible izango. Estrategia hau darabilten hizkuntzetako bat latina da. Latinean velle 'nahi' aditzarekin (nolle ezeztapenerako forma duenarekin) soilik erabil daiteke ihesbide hau (56c).

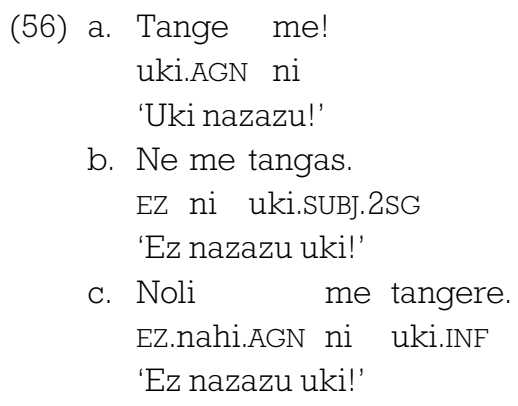

(Postma \& Van der Wurff, 2007, 239)

Salbuespen hauek inkorporazioaren bidez azal badaitezke ere, Postma eta Van der Wurffek $(2007,241)$ bestelako kontra-adibideak ere ematen dituzte: bulgarieraz ezeztapen anaforikoa eta perpaus barnekoa berdinak dira, eta gainera ezeztapenean, ezeztapen partikula eta aditza ez dira batera azaltzen, inkorporaziorik ez dagoela agerian utziz:

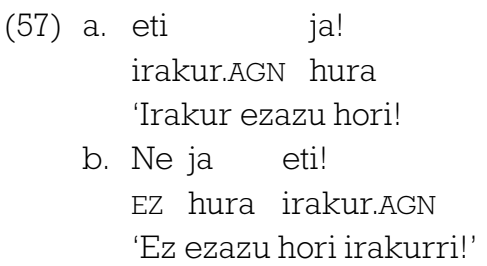

Arazo honen irtenbide gisa pentsa liteke bulgarierak ez duela agintera konposizional emankorrik, izan ere, Scatton-ek (1993 apud Postma \& Van der Wurff, 2007) ikusi zuen bulgarierako aginteran ezin dela ezeztapena erabili adizki burutuekin, eta agintera eta ezeztapena, biak batera, adizki burutugabeekin bakarrik gerta daitezkeela. Gainera, adizki burutugabeekin ere, (57b) bezalako perpausak baino ohikoagoak dira estrategia osagarriak erakusten dituztenak (Postma \& Van der Wurff, 2007, 242).

Ezeztapena eta agintera gertatzea ahalbidetzen duten bestelako estrategiei dagokienez (subjuntiboaren eta infinitiboaren erabilerari dagokienez, esaterako), Zanuttinik (1997 apud Postma \& Van der Wurff, 2007, 244) erakutsi zuen estrategia hauek portaera sintaktiko zenbaitetan benetako aginterak bezala jokatzen dutela, adibidez, klitikoen kokalekuari dagokionez.

Zanuttinik (1997) beste iradokizun interesgarri bat ere egiten du: beharbada estrategia osagarri hauetan ezeztapenak berak hartzen duela aginteraren rola, hau da, ezeztapenak KONP-erako mugimendua egitean aginteraren ([AGN]) ezaugarriak hartzen dituela:

(58) non $_{\mathrm{i}}-$ lo t $_{\mathrm{i}}$ fare 
Halako egituretan aditzak ez du, berez, [AGN] ezaugarririk, morfologikoki forma erregularra (kasu honetan infinitiboa) duenez gero. Hortaz, Postma eta Van der Wurffen (2007) arabera, gauza bat eta bera dira KONP-en [AGN] ezaugarriak hartzen dituen ezeztapena eta aginteran estrategia osagarria eragiten duen ezeztapena. Ezezkako agintera bestelako estrategia osagarririk gabe darabilten hizkuntzetan, hortaz, ezeztapenak ez du [AGN] ezaugarririk hartzen, aditzak berak hartzen du eta.

Hortaz, Postma eta Van der Wurffek (2007) adierazten dute Gramatika Unibertsalak ezeztapena kokatzeko bi islapen dituzten hizkuntzetan (A/A-barran banatuta) agintera eta ezeztapena gertatzea ahalbidetzen duela. Halako estruktura duten hizkuntzetan aditzaren KONP-erako mugimendua islapen hauetako bat zeharkatuz egiten da, bestea saihestuz, inolako urratzerik egin gabe. Ezeztapen anaforikoaren eta perpaus barnekoaren arteko desberdintasun formalik ez dagoen hizkuntzetan, bi islapenak lotuta daude eta aditzaren mugimendua eragozten du hesi bezala jokatzen duen islapen bateratu horrek. Baina bi islapenen lotura horrek, era berean, bestelako bideak irekitzen ditu: ezeztapenaren inkorporazioa duten hizkuntzetan aditza ezeztapenarekin elkar daiteke KONP-erako bidean inolako urraketarik sortu gabe, edo bestela, ezeztapenak berak, KONP-era mugitzearekin batera, [AGN] ezaugarriak har ditzake mugimendu desegokirik eragin gabe.

Euskarara itzuliz, lehen esan bezala, ez dago ezeztapena egiterik adizki sintetikoekin, eta forma analitikoekin, berriz, hizkeren arteko aldea antzematen dugu: erdialde eta mendebaldean ez bezala, ekialdean subjuntibora jo behar dute. Aditz jokatugabeekin, berriz, ez mendebaldean ez ekialdean, ez dago inolako arazorik ezeztapenean.

Euskalkien arteko aldeari dagokionez, aipatzeko modukoa iruditzen zait hizkeren arteko aldakortasun hau aspaldi xamarrekoa izatea. Lakarra eta Mounolek $(2015,73)$ 1400 eta 1600 urteen arteko euskarari buruz diotenaren arabera, «debeku baten adierazteko, ekialde eta erdialdeko testuek [...] -(e)la adizkidun oraineko formak erabiltzen dituzte (errozue vs ezterrozuela Leiz, begira ezazue vs eztezazuela dei Leiz). Mendebaldean, berriz, aginterazko adizkiei eusten zaie, eta ezezkako partikula da aldatzen dena, $e z$ beharrean, ze erabiltzen baita».

(59) a. Ezca çe aquio daucanari ta vay onderextanari.

$(R S$ 257)

'Ez iezaiozu eskatu daukanari eta bai maite zaituenari.'

b. Esan ce eguidaçu berva oriec.

'Ez iezazkidazu esan berba horiek.'

(59)-ko adibideetan, adizki analitikoen gramatikalizazio-maila apalaren erakusgarri den hitz-ordena berezia alde batera utziz (ezezkako partikula adizki analitikoetako aditz nagusiaren eta laguntzailearen artean kokatzen baitzen), mendebaldean perpaus barneko ze ezeztapen partikula bizirik zegoela ikus daiteke, geroago desagertuko zena. Hori dela eta, Postma eta Van der Wurffek (2007) diotenarekin lotuz, beharbada pentsa liteke mendebaldean $e z$ eta $z e$ partikulak egoteak ahalbidetzen zuela ezeztapeneko agintera, eta, aldiz, ekialdean, $e z$ partikula soilik egotean, estrategia osagarri batera jo beharra zutela, -(e)la konplementatzailearen erabilerara, hain justu. 
Egoera haren arrastoak gaur egundaino iritsi zaizkigula pentsatzeak, ordea, ez du azaltzen gaurko egoera konplexua, non hizkeren arteko aldakortasuna alde batera utzita, sintetikorik ezin den erabili ezeztapenarekin batera, ez ekialde ez mendebaldean, eta aditz jokatugabeak, berriz, euskalki guztietan erabil daitezkeen ezezkako perpausetan.

\section{ONDORIOAK}

Lan honetan zehar azaldu dudan bezala, euskarako benetako aginte perpausak 2 . pertsonako subjektua dutenak dira, ezaugarri sintaktikoek, morfologikoek eta semantikoek erakusten dutenez.

Hala ere, hizkuntza guztietan ez da hala. Zenbait hizkuntzatan, perpaus hortatiboetako adizkiak aginterakoak bezalakoak dira eta honek iradokitzen du badagoela harreman bat bi perpaus moten artean. Zanuttiniren (2008) lanak sintaktikoki erlazionatzen ditu aginterako perpausak eta 2. pertsonaz kanpoko subjektuak dituzten aginte perpaus ez-kanonikoak, indar direkzionala duten perpaus hauetan guztietan subjektua baino goragoko islapen bat dagoela iradokiz.

Ikusi dugun moduan, aginteran isileko subjektua egon daiteke komunztadurarik edo aditz inflexiorik gabeko perpausetan, eta ingelesa bezalako subjektu isiltzerik gabeko hizkuntzatan, beste perpausetan ez bezala, aginteran subjektua isil daiteke. Ezaugarri honen arrazoia Sintagma Jusiboaren (Zanuttini 2008) agerpena da. Honela, aditzak pertsona ezaugarriak falta dituenean subjektutik gertuen dagoen eta pertsona ezaugarriak dituen elementutik, hau da, Sintagma Jusiboko burutik, jasoko ditu 2. pertsonako ezaugarriak komunztadura erlazio baten bidez. Gainera, Sintagma Jusiboaren proposamenak, 2. pertsonako subjektua duten aginte perpaus kanonikoez gain, estrategia osagarriak darabiltzaten perpausak ere barruan hartzen ditu. Hauetan, alabaina, subjektuaren eta Sintagma Jusiboaren artean pertsona ezaugarriak dituen beste islapen bat dagoenez, komunztadura erlazioa oztopatzen da.

Euskarari dagokionez, aginte perpaus kanonikoek eta ez-kanonikoek ezaugarri komun batzuk dituztela ikusi dugu. Euskaraz, 1. pertsonako subjektudun perpausek aginteraren ezaugarriak erakusten dituzte, hala nola, diskurtsoko partaideekiko lotura estua edo subjektuan betekizun bat ezartzea. Hauetan bezala, indar direkzionala duten 3. pertsonako subjektudun perpausetan ere Sintagma Jusiboa dagoela proposatu dut.

Bukatzeko, ezeztapena eta agintera batera agertzen direnean sortzen diren gertakariei bagagozkie, lanean zehar ikusi dugu Postma eta Van der Wurffen (2007) analisiak, euskara arkaikoko aginte perpausen ezeztapena aztertzeko balio duela dirudien arren, ezin duela egungo euskara azaldu. Beraz, ikerketa gehiagoren beharra dago adizki sintetikoekin hizkera guztietan eta adizki analitikoekin ekialdeko hizkeretan gertatzen diren murriztapenak azaldu ahal izateko. 


\section{ERREFERENTZIAK}

Aikhenvald, A. Y. (2010). Imperatives and Commands. Oxford: Oxford University Press. Alcázar, A. \& Saltarelli, M. (2014). The Syntax of Imperatives. Cambridge: Cambridge University Press.

Artiagoitia, X. (2000). Hatsarre eta parametroak lantzen. Gasteiz: Arabako Foru Aldundia.

Artiagoitia, X. (2012). The DP Hypothesis in the grammar of Basque. In U. Etxeberria, R. Etxepare \& M. Uribe-Etxeberria (arg.), Noun Phrases and Nominalization in Basque: Syntax and semantics (21-78 orr.). Dordrecht: John Benjamins.

Azkue, R. M. (1925). Morfología Vasca. Bilbo: La Gran Enciclopedia Vasca.

Bennis, H. (2006). Agreement, pro and imperatives. P. Ackema, P. Brandt, M. Schoorlemmer \& F. Weerman (arg.), Arguments and agreement (101-123 orr.). Oxford: Oxford University Press.

Berro, A. (2015). Breaking verbs. From event structure to syntactic categories in Basque. Doktore tesia. UPV/EHU \& Université Bordeaux Montaigne (UBM). Hemendik hartua: http://basdisyn.net/pdf/Berro\%20tesia1009.pdf

Birjulin, L.A. \& Xrakovskij, V. S. (2001). Imperative sentences: theoretical problems. V.S. Xrakovskij (arg.), Typology of Imperative Constructions (3-54 orr.). Munich: LINCOM Europa.

De Rijk, R. P. G. (2008). Standard Basque. A Progressive Grammar. Cambridge MA: The MIT Press.

Duguine, M. (2010). Argumentu isilak eta hizkuntz aldakortasuna. Bilbo: Udako Euskal Unibertsitatea.

Etxeberria, U. (2010). - $a$, -ak eta -(r)ik euskal hizkeretan zehar. B. Fernandez, P. Albizu eta R. Etxepare (arg.), Euskara eta euskarak. Aldakortasun sintaktikoa aztergai (65-83 orr.). Bilbo: UPV/EHU.

Etxepare, R. (2003). Negation. Hualde, J. I. \& Ortiz de Urbina, J. (arg.), A grammar of Basque (516-563 orr.). Berlin: Mouton de Gruyter.

Euskaltzaindia. (1987). Euskal Gramatika. Lehen Urratsak-II (EGLU-II). Bilbo: Euskaltzaindia.

Euskara Institutua, EHU. Agintera perpausa. Sareko Euskal Gramatika (SEG). www. ehu.eus/seg helbidetik berreskuratua.

Hualde, J. I. \& Ortiz de Urbina, J. (arg.). (2003). A grammar of Basque. Berlin: Mouton de Gruyter.

Hualde, J. I., Oyharçabal, B. \& Ortiz de Urbina, J. (2003). Finite forms. In Egileak (arg.), A grammar of Basque (205-245 orr.). Berlin: Mouton de Gruyter.

Kayne, R. (1993). Towards a Modular Theory of Auxiliary Selection. Studia Linguistica 47-1, 3-31.

Lakarra, J. A. \& Mounole, C. (argitaratzeko). Euskara Arkaikoa. J. Gorrochategui, I. Igartua \& J. A. Lakarra (arg.), Euskararen Historia. Gasteiz: Eusko Jaurlaritza.

Lewis, M. P., Simons, G. F. \& Fennig, C. D. (arg.). (2016). Ethnologue: Languages of the World, Nineteenth edition. Texas: SIL International. Hemendik hartua: http://www.ethnologue.com 
Mauck, S., Pak, M., Portner, P. \& Zanuttini, R. (2005). Imperative subjects: A Crosslinguistic Perspective. C. Brandstetter \& D. Rus (arg.), Georgetown University Working Papers in Theoretical Linguistics (135-152 orr.). Georgetown University.

Mitxelena, K. (1960). Gipuzcoano y vasco. J. A. Lakarra \& I. R. Arzalluz (arg.) (2011) Luis Michelena. Obras Completas. VII. Fonética y Fonología, Morfosintaxis y Dialectología (697-700 orr.). Donostia \& Gasteiz: EHU.

Oyharçabal, B. (2000). Note à propos des formes jussives préfixées en $b$ - du basque. Lapurdum, 5, 225-235.

Oyharçabal, B. (2003). Tense, aspect and mood. Hualde, J. I. \& Ortiz de Urbina, J. (arg.), A grammar of Basque (249-283 orr.). Berlin: Mouton de Gruyter.

Ortiz de Urbina, J. (1989). Parameters in the Grammar of Basque. Dordrecht: Foris.

Portner, P. (2005). The Semantics of Imperatives within a Theory of Clause Types. K. Watanabe \& R. B. Young (arg.), Proceedings of Semantics and Linguistic Theory, 14, 235-252. New York: CLC Publications.

Postma, G. \& Van der Wurff, W. (2007). How to say no and don't: Negative imperatives in Romance and Germanic. W. Van der Wurff (arg.), Imperative clauses in generative grammar (205-249 orr.). Amsterdam \& Philadelphia: John Benjamins Publishing Company.

Potsdam, E. (1998). Syntactic Issues in the English Imperative. New York: Garland.

Scatton, E. (1993). Bulgarian. B. Comrie \& G. Corbett (arg.), The Slavonic Languages (188-248 orr.). London: Routledge.

Visser, F. Th. (1966). An Historical Syntax of the English Language. II Syntactical Units with One Verb (Continued). Leiden: E. J. Brill.

Zanuttini, R. (1997). Negation and Clausal Structure: A Comparative Study of Romance Languages. New York: Oxford University Press.

Zanuttini, R. (2008). Encoding the addressee in the syntax: evidence from English imperative subjects. Natural Language \& Linguistic Theory, 26, 185-218.

114 Fontes Linguae Vasconum (FLV), 123, enero-junio, 2017, 87-114

ISSN: 0046-435X ISSN-e: 2530-5832 